\title{
Irfani
}

ISSN 1907-0969 E ISSN 2442-8272

Volume 14 Nomor 2 Desember 2018

Halaman 97-100

http://journal.iaingorontalo.ac.id/index.php/ir

\section{Penerapan Strategi Pembelajaran Resource-Based-Learning (RBL) Dalam Meningkatkan Hasil Belajar Siswa Pada Mata Pelajaran IPA di Kelas VII SMP Negeri 10 Kota Gorontalo}

\author{
Zohra Waty Hiola \\ IAIN Sultan Amai Gorontalo
}

\begin{abstract}
Abstrak
Studi ini bertujuan untuk mengetahui hasil aktivitas belajar peserta didik yang dibelajarkan dengan menggunakan strategi pembelajaran resource-basedlearning (RBL). Penelitian ini dilaksanakan dengan menggunakan metode quasi eksperimen atau eksperimen semu dan data yang diperoleh dianalisis dengan menggunakan uji ANAVA 2 × 2. Hasil penelitian ini menunjukkan bahwa hasil belajar IPA peserta didik yang dibelajarkan dengan strategi pembelajaran RBL meningkat. Hal ini ditunjukkan pada pengujian hipotesis yang menunjukkan bahwa $F_{\text {hitung }}>F_{\text {tabel }}$ atau $80,9094>4.05$ pada $\alpha=0,05$ artinya ada pengaruh yag signifikan dalam penerapan strategi pembelajaran RBL terhadap hasil belajar peserta didik.
\end{abstract}

\section{Kata Kunci : Strategi pembelajaran, hasil belajar, resource-based-learning (RBL).}

\section{PENDAHULUAN}

Pembelajaran IPA bertujuan untuk membekali anak dengan keterampilan dan memberikan pengetahuan tentang lingkungan sebagai tempat hidup manusia ${ }^{1}$. Untuk mencapai tujuan tersebut, tentunya dalam membelajarkan IPA haruslah dengan cara yang menyenangkan dan mudah dipahami oleh siswa. Selama ini dalam pembelajaran IPA masih didominasi oleh kegiatan yang berpusat pada guru. Aktivitas siswa dapat dikatakan hanya sebatas mendengarkan penjelasan. Penjelasan tersebut hanya sebatas produk dan sedikit proses serta membuat siswa kurang aktif dalam percobaan dan tidak mampu untuk menemukan konsep sesuai dengan pemikirannya sendiri. Hal ini akan berpengaruh langsung pada minat belajar dan aktivitas belajar siswa. Untuk meningkatkan minat belajar dan aktivitas belajar siswa khususnya pembelajaran IPA diperlukan strategi pembelajaran untuk mencapai tujuan pembelajaran.

Menurut Wena ${ }^{2}$, bahwa dengan strategi pembelajaran mempermudah menjalankan proses pembelajaran sehingga dapat mencapai hasil yang optimal. Tanpa strategi yang jelas, proses pembelajaran tidak akan terarah dan tujuan pembelajaran yang telah ditetapkan sulit tercapai secara optimal juga, dengan kata lain pembelajaran tidak dapat berlangsung secara efektif dan efisien. Penggunaan beberapa strategi dalam kegiatan

\footnotetext{
${ }^{1}$ Kresnadi, Heri. 2007. Pengembangan Pembelajaran IPA. Jakarta : Dirjen Dikti.

${ }^{2}$ Wena, Made. 2009. Strategi Pembalajaran Inovatif Kontemporer Suatu Tinjauan Konseptual Operasional. Jakarta : Bumi Aksara.
} 
belajar-mengajar akan membuat peserta tidak bosan dan mempunyai minat yang tinggi. Menurut Sulistyorini ${ }^{3}$, bahwa dalam strategi pembelajaran mencakup berbagai pendekatan, media pembelajaran, aneka sumber belajar, pengelolaan kelas, evaluasi dan waktu yang digunakan untuk mencapai tujuan agar siswa lebih aktif belajar dan berbuat untuk membangun pengetahuannya sebelum memahami konsep, hukum, prinsip-prinsip dan penerapan IPA. Ada beberapa strategi pembelajaran yang banyak menggunakan berbagai pendekatan, media pembelajaran, aneka sumber belajar, evaluasi, dan penggunaan waktu salah satunya adalah strategi pembelajaran Resource-Based-Learning (RBL). Jenis strategi ini masih kurang diterapkan di sekolah-sekolah.

Diketahui bahwa strategi pembelajaran RBL merupakan strategi yang langsung menghadapkan siswa dengan suatu atau sejumlah sumber belajar baik secara individual maupun kelompok dengan berbagai kegiatan belajar. strategi pembelajaran seperti ini memberikan kebebasan kepada siswa untuk belajar sesuai dengan minat dan kebutuhannya ${ }^{4}$.

Berdasarkan uraian tersebut, berikut ini dipaparkan mengenai karakteristik strategi pembelajaran Resourced Based Learning diantaranya Pembelajaran terdiri atas berbagai komponen yang meliputi pengajaran langsung oleh guru dan penggunaan aneka sumber belajar; Proses pembelajaran memanfaatkan sepenuhnya segala sumber informasi sebagai sumber pelajaran dan memberikan kesempatan kepada pendidik untuk merencanakan kegiatan belajar dengan mempertimbangkan aneka sumber yang ada; Guru memberikan kesempatan kepada siswa untuk belajar dari berbagai sumber dan mendapatkan jawaban yang harus diselidiki kebenarannya dari data yang dikumpulkan; Siswa di hadapkan kepada suatu atau sejumlah sumber belajar secara individual atau kelompok; Interaksi yang terjadi bertujuan mengganti pasivitas peserta didik dalam belajar tradisional dengan belajar aktif didorong oleh minat; Memberi kesempatan kepada peserta didik untuk belajar menurut kecepatan dan kesanggupan masing-masing; Mengembangkan kepercayaan terhadap diri sendiri dalam hal belajar yang memungkinkan peserta didik belajar sepanjang hidup ${ }^{5}$. Strategi tersebut jika diterapkan, diharapkan akan meningkatkan hasil belajar peserta didik ${ }^{6}$.

\section{METODE PENELITIAN}

Penelitian ini dilaksanakan di SMP Negeri 10 Kota Gorontalo selama 3 (tiga) bulan dan Kelas yang dijadikan subyek penelitian adalah kelas VII yang terdiri atas VII A, VII B dan VII C. Populasi dalam penelitian ini adalah seluruh siswa SMP Negeri 10 kota Gorontalo yang duduk di kelas VII. Siswa di kelas VII terdiri atas 3 kelas yaitu VII A, VII B dan VII C dan berjumlah 105 orang siswa. Teknik pengambilan sampel pada penelitian ini yakni menggunakan teknik Simple Random Sampling. Tujuan menggunakan teknik ini adalah setiap unsur dari keseluruhan populasi mempunyai kesempatan yang sama untuk dipilih. Penetapan jumlah kedua kelas sampel dilakukan secara random dengan teknik undian.

Analisis data yang digunakan pada penelitian ini dalam dua tahap. Tahap pertama disajikan dalam bentuk deskripsi data mengenai rentangan skor yang diperoleh, setelah

\footnotetext{
${ }^{3}$ Sulistyorini. 2007. Model Pembelajaran IPA Sekolah Dasar dan Penerapannya dalam KTSP. Semarang. Tiara Wacana.

${ }^{4}$ Nasution, 2008. Berbagai Pendekatan Dalam Proses Belajar Dan Mengajar. Bandung : Bumi Aksara.

${ }^{5}$ Yusuf, Yustini dan Mariani Natalina. 2005. Upaya Peningkatan Hasil Belajar Biologi Melalui

Pembelajaran Kooperatif Dengan Pendekatan Struktur Di Kelas 17 SLTP Negeri 20 Pekanbaru. Jurnal Biogenesis Volume. 2(1):8-12, 2005 ISSN 1829-5460. Program Studi Pendidikan Biologi FKIP Universitas Riau.

${ }^{6}$ Syah, Muhibbin.2008. Psikologi Pendidikan dengan Pendekatan Baru. Bandung: Remaja Rosdakarya.
} 
itu distribusi, frekuensi, modus, median, rata-rata hitung, standar deviasi dan grafik histogram untuk masing-masing kelompok data. Tahap kedua dilakukan pengujian hipotesis yang didahului dengan persyaratan analisis normalitas dan homogenitas varians. Untuk pengujian hipotesis penelitian digunakan analisis varians dengan uji $\mathrm{f}$ pada taraf signifikan alpha $=0,05$. Analisis ini bertujuan untuk mengetahui pengaruh strategi pembelajaran dan minat belajar siswa terhadap hasil belajar IPA.

Jika hasil analisis varians terhadap variabel terikat dan terdapat interaksi antara variabel bebas perlakuan dan atribut terhadap variabel terikat, maka analisis dilanjutkan dengan uji Tuckey.

\section{HASIL DAN PEMBAHASAN}

Hasil pengujian menunjukkan bahwa $F_{\text {hitung }}>F_{\text {tabel }}$ atau 80,9094 $>4.05$ pada $\alpha=$ 0,05 artinya hipotesis H1yang menyatakan menyatakan terdapat perbedaan hasil belajar antara siswa yang diajar dengan menggunakan strategi pembelajaran Tipe RBL dan yang diajar dengan menggunakan strategi pembelajaran pembanding. Dengan demikian dapat dikatakan bahwa strategi pembelajaran RBL memberikan pengaruh pada hasil belajar peserta didik pada mata pelaara IPA. Hal ini berarti pemberian perlakuan strategi pembelajaran Tipe RBL lebih unggul dari strategi pembelajaran pembanding.

\section{SIMPULAN DAN SARAN Simpulan}

Berdasarkan hasil pengujian hipotesis dan pembahasan penelitian maka dapat disimpulkan bahwa terdapat pengaruh penerapan strategi pembelajaran RBL terhadap hasil belajar peserta didik pada mata pelajaran IPA. Bentuk pengaruh tersebut adalah peningkatan hasil beajar peserta.

\section{Saran}

Setiap strategi pembelajaran memiliki kelebihan dan kekurangannya, untuk itu mengukur hasil belajar siswa perlu disesuaikan dengan tujuan pembelajaran yang ingin dicapai, tingkat kemampuan yang diukur, jenis dan jenjang pendidikan, efisiensi waktu dan ruang lingkup materi yang diuji. Pengetahuan, keterampilan dan kreativitas para guru dalam hal mencoba berbagai macam strategi pembelajaran yang meningkatkan motivasi dan minat belajar siswa sehingga aktivitas belajar siswa akan lebih baik.

Untuk dapat lebih mengoptimalkan aktivitas belajar siswa pada mata pelajaran IPA Biologi khususnya pada materi upaya mengatasi kerusakan dan pencemaran lingkungan sebaiknya lebih memanfaatkan fasilitas sekolah seperti media, lapangan, perpustakaan dan masih banyak lagi fasilitas lainnya. Selanjutnya bagi para peneliti yang berkeinginan untuk melanjutkan dan mengembangkan penelitian ini dengan menggunakan variabel berbeda, diharapkan untuk lebih melakukan kontrol lebih ketat dalam seluruh rangkaian proses pembelajaran.

\section{DAFTAR PUSTAKA}

Kresnadi, Heri. 2007. Pengembangan Pembelajaran IPA. Jakarta : Dirjen Dikti.

Nasution, 2008. Berbagai Pendekatan Dalam Proses Belajar Dan Mengajar. Bandung : Bumi Aksara. 
Rosmarini, S. Evi Suryawati dan Mariani N. L. 2004. Penerapan pendekatan Struktural Think-Pair-Share (TPS) Untuk Meningkatkan Hasil Belajar Dan Aktivitas Peserta didik Kelas I.7 SLTPN 20 Pekanbaru pada pokok bahasan keanekaragaman hewan ta. 2002/2003.Jurnal BiogenesisVol. 1(1):9-14, 2004. ISSN : 1829-5460. Riau : Program Studi Pendidikan Biologi FKIP Universitas Riau.

Sudjana. 2006. Metoda Statistika. Bandung : Tarsito.

Sulistyorini. 2007. Model Pembelajaran IPA Sekolah Dasar dan Penerapannya dalam KTSP. Semarang. Tiara Wacana.

Syah, Muhibbin.2008. Psikologi Pendidikan dengan Pendekatan Baru. Bandung: Remaja Rosdakarya.

Wena, Made. 2009. Strategi Pembalajaran Inovatif Kontemporer Suatu Tinjauan Konseptual Operasional. Jakarta : Bumi Aksara.

Yusuf, Yustini dan Mariani Natalina. 2005. Upaya Peningkatan Hasil Belajar Biologi Melalui Pembelajaran Kooperatif Dengan Pendekatan Struktur Di Kelas 17 SLTP Negeri 20 Pekanbaru. Jurnal Biogenesis Volume. 2(1):8-12, 2005 ISSN 1829-5460. Program Studi Pendidikan Biologi FKIP Universitas Riau. 